\title{
Combating Increasing Chronic Non Communicable Diseases: The Need, Progress and Way Forward for Health Promoting Schools in South Africa
}

\author{
Natisha Dukhi ${ }^{*}, 1$ and Sunitha Srinivas ${ }^{2}$ \\ ${ }^{1}$ Medical Scientist, Durban University of Technology, Durban-4000, South Africa \\ ${ }^{2}$ Faculty of Pharmacy, Rhodes University, PO Box 94, Grahams town, 6140, South Africa
}

\begin{abstract}
Epidemic increase in chronic non-communicable diseases (CNCDs) is resulting in immense challenges in developing countries such as South Africa. Previously misunderstood to affect only high-income countries, $80 \%$ deaths due to CNCDs occur in developing countries. This review article traces the path of health promotion in the Eastern Cape and South Africa while considering health promotion developments globally. An example is the HealthPromoting school initiative in 180 schools in the Eastern Cape Province based on the World Health Organization's Health-Promoting School Initiative. Alma Ata's holistic 'health for all' ideals, the WHO's 'Right to health' along with South Africa's Bill of Rights have remained important paper based progress. However partial implementation of certain policies and lack of implementation of most broad based health promotion is a major challenge in South Africa which has to be addressed urgently to reverse the advancing CNCD epidemic. Keeping healthy population healthy and training them to prevent CNCDs to the maximum possible extent is feasible by strategically focusing on Health promoting schools in South Africa. Community participation, women's organizations and youth participation are critical in implementing Health promoting schools in South Africa while being supported by the intersect oral cooperation of key stakeholders in the Department of Health, Department of Education and community engagement services of Universities.
\end{abstract}

Keywords: Health promotion, schools, interventions, lifestyle, South Africa, Chronic Non Communicable Diseases

\section{INTRODUCTION}

Chronic non-communicable diseases (CNCDs) are a rising global threat and this burden is expected to rise from $46 \%$ in 2001 to approximately $60 \%$ by the year $2020 .^{1}$ Obesity, cardiovascular diseases (CVD) and diabetes contribute to almost half of the total mortality rate due to $\mathrm{CNCDs}$, and this trend is of great concern due to the emergence of these diseases early in life. ${ }^{1,2}$ Though CNCDs are a major challenge in middle and low-income countries, the notion of chronic diseases affecting only the affluent, continues. Due to complex interplay of risk factors that include unhealthy diet and lifestyle choices, the rate of increase of CNCDs in developing countries is currently higher than it was half a century ago in industrialized regions, resulting in one of the myths that CNCDs cannot be prevented effectively. ${ }^{2}$ Not only will these diseases contribute to increasing human morbidity and mortality but they will also affect many national economies, due to their impact on the 'productive age groups'. ${ }^{3}$ Bottom up participatory approaches for healthy lifestyle interventions and reduction of risk factors are vital as effective implementation of policies which are generally top down also needs people and communities
Submitted Date : 13-05-2014 Accepted Date : 11-06-2014

DOI: $10.5530 /$ ijopp.7.3.2

Address for correspondence: Ms Natisha Dukhi Durban University of Technology, Durban, SOUTH AFRICA

Phone: 0315784348

E-mail: natishadukhi@ yahoo.co.uk

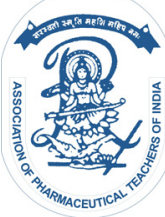

www.ijopp.org 
participating as part of bottom up approach. Instead of implementation of the "one size fits all" approach, community centered research to be conducted has to be worked out between researcher and the local communities.

The scale-up and strengthening of health promoting schools in Eastern Cape is of dire need to combat the increasing burden of CNCDs. Thus the objectives of this review article is to trace the development of health promotion in the global context- and then the aspects of need for establishing, strengthening, monitoring and evaluating health promotion in the Eastern Cape and other provinces of South Africa. A snowball referencing method was used to trace the development of health promotion in the Eastern Cape and South Africa.

\section{Health Promotion - Global Developments}

The World Health Organization (WHO) shifted its focus during the 1980s from the "behavior of individuals to the development of healthy settings." The Ottawa Charter for Health Promotion was adopted in 1986 to define health promotion from an eco-holistic approach, and health was seen as more than just an absence of illness or bad lifestyle choices. The vision for health has grown beyond the health sector and influencing health determinants, to incorporate reorientation of health services, creation of supportive environments, and development of personal health behavior skills as well as policies for public health.

Communicable diseases such as HIV/AIDS and tuberculosis (TB) receive much attention in South Africa. ${ }^{4}$ However while communicable diseases will continue to predominate, $\mathrm{CNCD}$ s will also continue to increase alarmingly, requiring focus and priorities simultaneously to both. ${ }^{5}$ Very few regions or countries have made significant changes in policy and programs that have resulted in positive dietary pattern shifts to decrease nutrition-related CNCDs. ${ }^{6}$ While some member states of WHO showed positive interest and began steering towards health promotion at national and local levels, resulting in actions to strengthen the preventive measures to counter the chronic disease epidemic from spreading, but developing countries are still far from implementing such measures. ${ }^{2}$

Some major milestones in Health promotion influenced by the World Health Organization are traced below. The Lalonde Report - A new Perspective on the Health of Canadians (1974) inspired the way forward for health promotion $^{7}$ and (Table 1) below highlights some of the major developments that occurred globally which influenced health promotion policies of Member states of the WHO, including South Africa. The ideology of Alma Ata influenced the growth of health promotion and was carried forward when Ottawa Charter was designed. ${ }^{8}$

Table 1: Milestones in health promotion

Ottawa Charter for Health Promotion, $1986 .{ }^{9}$

Adelaide Recommendations on Healthy Public Policy, $1988 .^{9}$

Sundsvall Statement on Supportive Environments for Health, $1991 .^{9}$

WHO's Expert Committee Recommendation on Comprehensive School Health Education and Promotion and WHO's Global School Health Initiative,1995. 10, 11 The Global School Health Initiative, launched in 1995, seeks to mobilize and strengthen health promotion and education activities at the local, national, regional and global levels. The Initiative is designed to improve the health of students, school personnel, families and other members of the community through school. ${ }^{10}$

Jakarta Declaration on Leading Health Promotion into the 21st Century, 1997.12

The global threat posed by NCDs and the need to provide an urgent and effective public health response was recognized by the World Health Assembly in 1998. A request was made to the Director-General of WHO to prepare a global strategy for NCD prevention and control (resolution WHA51.18).

School health component of the Mega Country Health Promotion Network, 1999. ${ }^{13}$

International Network of Health Promotion Foundations, 1999. ${ }^{14}$

Mexico Ministerial Statement for the Promotion of Health: From Ideas to Action, 2000

WHO Global Strategy for the prevention of NCDs, World health Assembly resolution (WHA/53.17), 2000. ${ }^{15}$

Global Forum on integrated NCD prevention and control, 2001. ${ }^{16}$

The Bangkok Charter for Health Promotion in a Globalized World, 2005

Nairobi Global Conference on Health Promotion, 2009 
The Resolution on Prevention and Control on CNCDs was adopted in May 2000 at the World Health Assembly (WHA), to guide member states in developing a 'national policy framework taking into account public policies to create a conducive environment for healthy lifestyles; as well as fiscal and taxation policies towards healthy and unhealthy goods and services'. ${ }^{17}$ The WHA Global Strategy on Diet, Physical Activity and Health was endorsed in 2004 in response to WHA 2002 (Resolution WHA 55.23), to assist developing countries to address, control and prevent CNCDs. ${ }^{1}$ A culturally suitable policy 'toolbox' has been developed for the different countries, with the strategy emphasizing that a multi-sect oral and multi-stake holder approach to CNCD reduction is essential to decrease the global disease burden. ${ }^{18}$

In April 2011, the first global ministerial conference on healthy lifestyle and non-Communicable disease control took place as a milestone in supporting the WHO member states in preventing and managing the impact of CNCDs. At the conference a commitment to action was made at the government, Ministry of Health and International level and included the following: making $\mathrm{CNCD}$ prevention and management priority, developing public policies incorporating many sectors in creating environments that are health promoting for the individual, household and community, integration of CNCD-related services into primary health care services, to strengthen health information systems that will monitor the CNCD burden, working with WHO and other multilateral organizations private sectors and stakeholders in communities to achieve optimum results in global health. September 2011 marked a significant turn of events with the first United Nations (UN) summit on CNCDs promoting growth in alliance groups that support $\mathrm{CNCD}$ research, aiming for the reduction of CNCD risk factors, as well as the strengthening of health systems. ${ }^{19}$

\section{Need for health promotion in South Africa}

South Africa, a middle income country, is still undergoing major transitions socially, economically and in health itself. With an estimated 49 million people, and despite $75 \%$ literacy, unemployment rate remains at $40 \% .^{20,21}$ In the South African population, approximately 56\% have at least one risk factor, with $20 \%$ at high risk of CNCDs. The 1998 SADHS revealed that $19.8 \%$ of adult males and $26.1 \%$ of adult females were overweight, while $9.3 \%$ of men and $30.1 \%$ of females were obese. Furthermore, $5.3 \%$ of male adolescents and $17.6 \%$ of female adolescents were overweight, while $2 \%$ of male and $5.9 \%$ of female adolescents was obese. ${ }^{22}$
In 2001, about 536 deaths occurred daily due to CNCDs and were expected to increase to 563 in 2010 . This necessitates urgent action to increase health promotion in South Africa ${ }^{17}$. The 2008 South African estimates revealed that $29 \%$ of deaths are due to CNCDs. While the figures may appear small in comparison to the remainder of death causes, the percentage of $\mathrm{CNCD}$ deaths under the age of 60 are $39.7 \%$ for males and $28.7 \%$ for females. The estimated prevalence of metabolic risk factors such as overweight and obesity is $65.4 \%$ and $31.3 \%$ respectively, with behavioral risk factors such as physical inactivity at $51.1 \%$ and tobacco use at $14.0 \%{ }^{23}$ The Eastern Cape Province is the second most poverty- struck province with $72 \%$ of the population surviving below the poverty income line $e^{24}$ and also has the second highest poverty gap at R14.8 billion. ${ }^{25}$ In the Eastern Cape, with 43\% of deaths occurring due to CNCDs, there is a need for national policies to be developed further and emphasized by local, provincial planners and other stakeholders to meet their community's health needs. Healthy lifestyle, health care access, risk factor reduction and major chronic disease burden contributor interventions are required to address the various health determinants. ${ }^{26,27}$

Policy makers are expected to conceptualize health in a way that will eradicate health inequalities as well as reduce health burdens. However, this will be unsuccessful if researchers who have access to the evidence on social determinants of health inequalities do not positively influence the decision of policy makers and governments to use health care services and healthy lifestyles to improve health. Population health inequalities can be reduced by the influence of municipal governments provided the researchers enhance the "health inequities knowledge base" 28 and pave the path towards healthy public policies, their implementation as well as monitoring and evaluation.

\section{Health promotion in South Africa}

The 1986 Ottawa Charter for health promotion was used as a guiding policy document for the national policy for health promotion practice in South Africa. ${ }^{29}$

Bill of Rights ${ }^{30}$ in South Africa articulated access to health care which was an extremely positive move. Health promotion first became a part of SA's health care system during the 1990's. However, during this time people who carried out health promotion services did not possess any formal training, leaving the confusion of health education and health promotion to continue. ${ }^{29}$ The confusion arose from dealing only with specific health aspects instead of adopting a "holistic approach to health promotion". Health promotion was seen as an application of strategies and principles to diseases, risk factors, the population groups and the setting., 31 
The concept of health promotion was reportedly adopted in 1994 by the Education, Health and Welfare ministries in South Africa, based on five key action areas: 'To promote safe environments for people to live and work in; To develop healthy public policy; To promote community action; To develop personal skills, and To re-orient the health services' ${ }^{29}$ In 1997, the National Health Promotion policy and the Health Promotion Foundation initiative (2002) were still at a draft stage at the cluster level but the HP Foundation initiative, according to Onya, ${ }^{32}$ is currently not progressing further at the Department of Health. The National Health Promotion Policy based on the Ottawa Charter was reported to be in a final draft process. ${ }^{29,} 32$ The change of Directorate between 1994 and 2007 occurring four times coupled with lack of proper influence of health promotion professionals and advocacy resulted in inadequate health promotion activities. $^{32}$

South Africa has adopted broad health concepts to include other key stakeholders from the health, education, industry, political and justice systems in developing health promotion for specific risk factors and target groups. ${ }^{1,33}$ Health promotion is reportedly based on inter-sect oral collaboration in South Africa because good health relies on various factors which include education, economy, water, sanitation, agriculture, telecommunication, housing and transport as recognized by the local, provincial and national governments., ${ }^{4}$, The South African Demographic and Health Survey provide insight of status of public health. ${ }^{22,32}$ The Medical Research Council (MRC), Health Systems Trust (HST), Human Sciences Research Council (HSRC), academic institutions, media and government information systems are all involved, contributing to public health research in SA. ${ }^{32}$ Though proliferation of health promotion services are reported by NGOs and community health workers who are supported by the National Health Promotion Directorate and funded by the national budget of the Department of Health, as well as international agencies ${ }^{35}$ there is a dire need for the evaluation and monitoring of these services.

Projects to promote health, such as the 'Healthy Cities' was designed by the Medical Research Council, local clinics, schools, the departments of health and education and environmental health services. Every city was to have a Steering committee so that support from local political groups could be raised. Each city was to decide its agenda and achieve outcomes and hence it was difficult to evaluate the project. ${ }^{36}$ The Department of Health Promotion has highlighted milestones achieved such as formation of national sports commission, introduction of life skills in curriculum, launch of national campaigns such as 'Vuka South Africa, Move for Health'. However consistent participation of stakeholders, competing demands and lack of intersect oral partnerships were identified as the key challenges in the progress of health promotion. ${ }^{37}$

\section{Health Promoting Schools}

Current health status regarding diet, physical activity, increased alcohol and tobacco use is a cause for concern ${ }^{23,38}$ because CNCDs are starting early in life and prevention has the potential to reduce the diseases appearing in adulthood. Positive influences of adopting and maintaining healthy dietary modifications and increased physical activity are influenced by a complex interplay of various factors that are more difficult to influence in adults ${ }^{39}$ when compared to young people. ${ }^{40}$ Students as young as 10-12 years of age are the targeted groups for healthier lifestyle interventions because enhanced knowledge and skills for choice of foods and physical activity habits have positive influence on their ability to take responsibility for their own health. ${ }^{41}$

Guided by the Ottawa Charter for Health Promotion ${ }^{8}$ and the Jakarta Declaration ${ }^{12}$ the WHO Global School Health Initiative was launched in 1995 to initiate Health Promoting Schools (HPS) that focus on 'constantly strengthening its capacity as a healthy setting for living, learning and working ${ }^{10}$, The HPS aim to link family and community to the school, focus on the entire school ethos, including attitudes of staff, style of management and policies for consistent messages of health to be received and given. ${ }^{42}$ Children, teachers, other school staff, parents and community are vital to work towards a culturally acceptable framework of interventions that responds to the local needs. ${ }^{43}$ Schools are seen as a key health promotion environment and the educational strategies are encouraged to extend beyond the curriculum to build a multidisciplinary approach that utilizes skills, communication, increased awareness of health, and use of health and support services ${ }^{39}$ to incorporate nutrition- and health literary into school learners. ${ }^{44}$ However, due to a structured curriculum at schools, there is often little or no time available to incorporate health issues ${ }^{21,45}$ and training for teachers in this regard is often poor or absent. ${ }^{39}$

\section{DISCUSSION}

\section{Status of HPS in SA and Eastern Cape}

According to the School Register of Needs Survey 1996, major problems in the schools' physical and social environments were identified, such as shortage 
of water, electricity, toilet facilities and classrooms in dilapidated school buildings. ${ }^{46}$ Further highlighting the problem were reports of alcohol/substance abuse, lack of nutrition, violence, smoking and 'deficiencies in early childhood development, child protection and social welfare' occurring in SA schools. ${ }^{47}$ After the HPS initiative implementation in 1999, 580 HPS were launched nationwide whereby the Departments of Health, Education, Social Development and Population Welfare focused on assisting these schools with clean water, proper sanitation facilities, vegetable gardens and billboard advertising harmful products such as smoking of cigarettes. Schools were supported based on the projects they chose..$^{29,32}$

The Eastern Cape is the leading province with 180 of the 580 HPS launched in SA and out of 6000 schools in the province. ${ }^{48}$ Some of the major activities include anti-tobacco programmes in 20 schools; paraffin safety workshops in three districts; food kitchen promotion; HIV/AIDS programmes and life skills education with the support of media, businesses government and NGOs. When the School-Based Food Gardens Project was launched in October 2005 by the Minister of Health in the Makana Local Services Area district in Grahams town, Eastern Cape, the importance of the school environment in which both learners and educators spend a vast amount of their time was highlighted. As young learners can be positively influenced, it was envisaged that the launching of the food gardens was the way forward to promote healthy eating- especially of fruits and vegetables, making healthy choices and promoting good health. ${ }^{49}$

The Umthathi Training Project (UTP), based in Grahams town, Eastern Cape, is a NGO, which aims to provide training and developmental education in organic cultivation methods with three main objectives: Agriculture, Community Development and School gardens. Community members are trained in acquiring skills for nutrition, cultivation and livelihood, enabling them to feed their families, as well as generate income from the produce in their gardens. In the school gardens programme, the school feeding scheme is supported and sustained by the vegetables grown in the school gardens. Learners are also encouraged to transfer their skills to family members and their community. As part of the school gardens programme, schools follow a three year programme and lessons taught include: Perm culture gardening; leadership and business skills; as well as health and nutrition. During the 2008-2009 period, 45 schools, of which 20 were in the local area and 25 in the outlying areas, participated in the programme, with various other schools enrolled in the first phase of the programme during $2010 . .^{50}$

\section{Way forward for health promoting schools in South Africa}

While it can be argued as to whether SA does indeed have adequate resources, for legislative frameworks and political will for health promotion to be effective, the mechanisms that demonstrate health promotion effectiveness must have key messages disseminated to influence its practice. Due to the diverse populations within South Africa, with differing habits, lifestyles and practices, the use of Western interventions is inappropriate. We need to develop and implement interventions that are culturally appropriate, specific for the various health situations, and target groups relevant to South Africa. ${ }^{17}$ A multidisciplinary approach is crucial for successful and sustainable health promotion. While many lifestyle school interventions have a behavioral theoretical framework that guides them, there should also be specific components that influence the interventions. For example, in a school obesity intervention, there should be modification of physical activity and dietary components, as well as nutrition and healthy lifestyle education that includes learners and parents for an extended duration so that the desired outcome can be exhibited by participants. ${ }^{51}$ One of the logistical barriers to health promotion is teachers and principals viewing health promotion during school time as a disruptive function that affects the operation of the school, is also a potential barrier. ${ }^{52}$ Multicultural diversity of SA requires creative, innovative, and multilinguistic health promotion. ${ }^{52,53}$

Identifying and assimilating successful examples from other countries is key in addressing local challenges in South Africa. Developed as a systematic and coordinated initiative, Brazil's dietary patterns initiative included changes to the national feeding program of schools, regulatory and legislative policies, to address obesity. ${ }^{54}$ South Korean government promoted traditional healthy diet, low in fat and rich in vegetables, by adopting intensive training for newlywed women to prepare traditional dishes. ${ }^{55,56}$ Coordinated in India, the Initiative for Cardiovascular Health Research in Developing Countries, and the Community Actions to Prevent Chronic Diseases are two international initiatives that address CNCDs in developing countries. These initiatives assist other developing countries by providing training and support for researchers in developing protocols and research questions to secure funding for CNCD research. ${ }^{57}$

South Africa takes a nose-dive in health promotion due to lack of evaluations on intervention impact. There is also a lack of published work in this area and according to the Director of Health in the SA National Department of Health; the focus is more on health education rather than targeting holistic health promo- 
tion. The Director highlighted the need to build strong links with other developing countries so that a stronger health promotion network can be established ${ }^{5}$. It is equally important to concentrate on long-term visions, by stimulating sectors other than health and avoiding unplanned interventions. Health Promotion requires proactive initiatives at the local, provincial and national action which are monitored and evaluated periodically. Building a dynamic and equitable society requires interdisciplinary and community-based education integrated into the health science curricula.

Despite financial resources supporting development of manpower, lack of trained health promotion personnel remains a problem in the Department of Health. ${ }^{35}$ Only six SA universities currently offer health promotion courses ranging from one day to two- week short courses, as well as BSc and MSc degrees that aim to provide skill and knowledge in the practice of health promotion. However, there is a current low student intake and a curriculum that is neither standardized nor streamlined ${ }^{32}$. While the delivery of health promotion at a national level may appear to be stable, provincial infrastructure disparities attenuate the problem. Only Mpumalanga province has a Health Promotion Practioners (HPP) career structure, with 86 of the 120 HPPs undergoing training and 34 having a basic diploma training. ${ }^{58}$ Capacity gaps in South Africa's health care system due to slow development of training opportunities and inadequate number of qualified professionals to lead health promotion has resulted in slow progress in reversing the CNCD epidemic. ${ }^{59}$

\section{RECOMMENDATION}

In identifying a holistic approach to address 'health for all', the Alma Ata declaration has paved the way forward by identifying health promotion and strengthened primary health care as important milestones to be achieved. However, in developing countries over the last thirty five years, progress in achieving these goals has been very slow. Despite being a Member state of WHO, partially implementing the Millennium Development Goals, as well as developing policies regarding health promotion, South Africa's vulnerable population has not yet benefitted from a paper or an operational level of these policies. Due to the challenges posed and the available resources utilized by communicable diseases, the goal of achieving health promotion will remain distant. Presently in South Africa, surveillance, prevention and health care system strengthening are not possible and so the refocusing of resources on health promoting schools is one of the best ways for- ward. To achieve positive impacts on families and society, we should aim to invest available resources on the next generation, continue to keep the healthy as they are. It is critical to include women and youth organization participation and communities in the implementation of South African health promoting schools. This must also be supported by multisectoral stakeholders such as university based community engagement services, the Department of Health and the Department of Education.

\section{CONCLUSION}

While expectations point to national governments to develop possible solutions to problems, it is equally essential that a bottom up participatory approach in schools, communities and society is adopted. Focusing and strengthening health promoting schools is a way forward to maintain and promote health of the healthy and young population of this country. Strategizing health promotion training for young female learners at schools will further enhance the positive impact on current and future families and the society in South Africa.

\section{ACKNOWLEDGEMENTS}

Dr S Robertson for the language editing of the draft paper

\section{COMPETING INTEREST}

The authors declare that they have no financial or personal relationship(s) which may have inappropriately influenced them in writing this paper

\section{AUTHORS' CONTRIBUTIONS}

This article is based on literature review and critical reflection based on a research project in which the authors have been involved. Both authors participated in the conception of the paper. ND led in drafting the paper. Both the authors reviewed and contributed to revising the paper, and approved the final version. The authors declare that they have no competing interests.

List of Abbreviations Used: Chronic non-communicable diseases (CNCDs), Cardiovascular Diseases (CVD), World Health Organization (WHO), Tuberculosis (TB), United Nations (UN), Medical Research Council (MRC), Health Systems Trust (HST), Human Sciences Research Council (HSRC), Health Promoting Schools (HPS), Umthathi Training Project (UTP), Health Promotion Practioners (HPP) 


\section{REFERENCES}

1. WORLD HEALTH ORGANIZATION Global strategy on diet, physical activity and health; 2004. Report No. WHA57.17. Available from http://www.who.int/ gb/ebwha/pdf_files/WHA57/A57_R17-en.pdf (Accessed 25 March 2010).

2. FOOD \& AGRICULTURE ORGANISATION Diet, Nutrition and the prevention of chronic diseases; 2003. Available from http://whqlibdoc.who.int/trs/WHO_ TRS_916. pdf (Accessed 25 March 2010).

3. Steyn K, Bradshaw D. Non-communicable disease surveillance in developing countries. Scandinavian Journal of Public Health. 2001; 29(1): 161-5.

4. Seiffge-Krenke I. Health Promotion in Schools. Social \& Behavioral Sciences. 2001: 1(1): 6598-602.

5. Unwin N, Setel P, Rashid S, Mugusi F, Mbanya JC, Kitange H, Hayes I, Edwards R, Aspray T, Alberti kgmm. Non-communicable diseases in subSaharan Africa: where do they feature in the health research agenda? Bulletin of the World Health Organization. 2001; 79(1): 947-53.

6. Popkin BM. Global nutrition dynamics: the world is shifting rapidly toward a diet linked with non-communicable diseases. American Journal of Clinical Nutrition. 2006; 84(2): 289-98.

7. WORLD HEALTH ORGANIZATION. Support to regions and countries in health promotion, strengthening national and community capacity. Available from http://www.who.int/healthpromotion/areas/regions/en/ (Accessed 19 May 2013)

8. WORLD HEALTH ORGANIZATION . The Ottawa Charter for Health Promotion; 1986. Available from http://www.who.int/healthpromotion/ conferences/previous/ottawa/en/(Accessed 15 May 2013). 1986:

9. WORLD HEALTH ORGANIZATION Milestones in health promotion: Statements from Global Conferences; 2009. Available from http://www.who. int/healthpromotion/milestones/en/index. html (Accessed 17 June 2010).

10. WORLD HEALTH ORGANIZATION Global school health initiative; 1995. Available from www.who.int/entity/school_youth_health/gshi/en/ (Accessed 28 May 2010).

11. WORLD HEALTH ORGANIZATION Promoting Health through Schools; 1997b. Available from http://whqlibdoc.who.int/trs/WHO_TRS_870. pdf (Accessed 19 May 2013).

12. WORLD HEALTH ORGANIZATION Jakarta Declaration on Leading Health Promotion into the 21st Century; 1997a. Available from http://www.who.int/ healthpromotion/conferences/previous/jakarta/declaration/en/index1. html (Accessed 15 may 2013).

13. WORLD HEALTH ORGANIZATION The school health component of the Mega Country Health Promotion Network; 1999a. Available from http://www. who.int/school_youth_health/mega/en/ (Accessed 20 May 2013).

14. WORLD HEALTH ORGANIZATION Network of Health Promotion Foundations; 1999b. Available from http://www.who.int/healthpromotion/ areas/foundations/en/ (Accessed 20 May 2013).

15. WORLD HEALTH ORGANIZATION Global strategy for the prevention and control of non communicable diseases; 2000. Available from http://apps. who. int/gb/archive/pdf_files/WHA53/ea14.pdf (Accessed 20 May 2013).

16. WORLD HEALTH ORGANIZATION Global Forum on Chronic Diseases Prevention and Control; 2001b. Available from http://www.who.int/chp/about/ global_forum/en/ (Accessed 20 May 2013).

17. MEDICAL RESEARCH COUNCIL 1995: An overview of Chronic Diseases of Lifestyle. Available from www.mrc.ac.za/chronic/cdloverview. pdf (Accessed 1 June 2010)

18. Waxman A. WHO's global strategy on diet, physical activity and health. Scandinavian Journal of Nutrition. 2004; 48(2): 58-60.

19. WORLD HEALTH ORGANIZATION First Global Ministerial Conference on Healthy Lifestyles and Noncommunicable Disease Control; 2011b. Available from http://www.who.int/nmh/events/moscow_ncds_2011/conference_ documents/moscow_declaration_en. pdf (Accessed 15 May 2013).

20. Sparling PB, Owen N, Lambert EV, Haskell WL. Promoting physical activity: the new imperative for public health. Health Education Research. 2000: 15(3): 367-76.

21. STATISTICS SOUTH AFRICA Mid-year population estimates 2010. Available from http://www.statssa.gov.za/default.asp (Accessed 17 September 2010).

22. Puoane $T$, Steyn K, Bradshaw D, Laubscher R, Fourie J, Lambert V, Mbananga R. Obesity in South Africa: The South African Demographic and Health Survey;2002. Available from http://www.obesityresearch.org/cgi/ content /full/10/10/1038 (Accessed 28 May 2010).
23. WORLD HEALTH ORGANIZATION 2011a: Non-communicable diseases country profiles 2011. Available from http://www.who.int/nmh/countries/zaf en. pdf (Accessed 13 October 2011).

24. HUMAN SCIENCE RESEARCH COUNCIL Fact Sheet: Poverty in South Africa; 2004. Available from www.sarpn.org.za (Accessed 18 May 2010).

25. STATISTICS SOUTH AFRICA Census 2001: Census in brief; 2003. Available from www.statssa.gov.za/census01/html/CInbrief/CIB2001. pdf (Accessed 17 September 2010).

26. Bradshaw D, Schneider M, Dorrington R, Bourne D, Laubscher R. South African cause of death profile in transition-1996 and future trends. South African Medical Journal. 2002; 92(1): 618-23.

27. Bradshaw D, Nannan N, Laubscher R, Groenewald P, Joubert J, Nojilana B, Norman R, Pieterse D, Schneider M. South African National Burden of Disease Study: Estimates of Provincial Mortality 2000. Available from: www. mrc.ac.za/bod/estimate. pdf (Accessed 15 June 2010).

28. Collins PA, Hayes MV. The role of urban municipal governments in reducing health inequalities: A meta-narrative mapping analysis. International Journal for Equity in Health. 2010; 9(13): 1-20.

29. Coulson N. Health Promotion in South Africa, Health Systems Trust update, issue No. 53. 2000. Available from http://www.hst.org.za/publications/381 (Accessed 15 June 2010)

30. SOUTH AFRICAN GOVERNMENT INFORMATION Bill of Rights; 2009. Available from http://www.info.gov.za/documents/constitution/1996/96cons2. htm (Accessed 20 May 2013)

31. Flisher AJ, Kramer RA, Hoven CW, King RA, Bird HR, Davies M, et al. Risk behavior in a community sample of children and adolescents. Journal of the American Academy of Child and Adolescent Psychiatry. 2000; 39(1): 881-7.

32. Onya H. Health promotion in South Africa. Promotion and education. 2007; 14(1): 233-237.

33. Nyamwaya D. Health promotion in Africa: strategies, players, challenges and prospects. Health Promotion International. 2003; 18(2): 85-7.

34. Andrew G, Pillay Y. Priorities for the national health system (2004-2009). (In South African Health Review. Durban: HST; 2005. pp 2-15).

35. DEPARTMENT OF HEALTH. South Africa Millennium Development Goals, Country Report; 2005. Available from www.doh.gov.za/docs/reports/2005/ $\mathrm{mdgd} /$ part4. pdf (Accessed 15 June 2010).

36. Strachan K. Health Promotion in South Africa, Health Systems Trust update, issue No. 53; 2000. Available from http://www.hst.org.za/publications/381 (Accessed 15 June 2010

37. Mthembu Z. Towards Implementation of the WHO Global Strategy on Diet, Physical Activity and Health: South African Experience; 2006. Available from http://www.who.int/dietphysicalactivity/strategy/southafrica\%20 presentation_wha59. pdf (Accessed 20 May 2013).

38. Groft JN, Hagen B, Miller NK, Cooper N, Brown S. Adolescent health: a rural community's approach. Rural and Remote Health. 2005; 5(1): 366. Available from http://www.rrh.org.au (Accessed 25 March 2010).

39. Pettman TL, Misan GMH, Owen, K, Warren K, Coates AM, Buckley JD, Howe PRC. Self-management for obesity and cardio-metabolic fitness: Description and evaluation of the lifestyle modification program of a randomised controlled trial. International Journal of Behavioural Nutrition and Physical Activity. 2008; 5(53): 53. Available from http://www.ijbnpa.org/content/5/1/53 (Accessed 25 March 2010).

40. Perez-rodrigo C, Klepp KI, Yngve A, Sjostrom M, Stockley L, Aranceta J. The school setting: an opportunity for the implementation of dietary guidelines. Public Health Nutrition. 2001; 4(2): 717-24.

41. Holcomb JD, Lira J. Evaluation of Jump into Action: A program to reduce the risk of non-insulin dependent diabetes mellitus in school children on the Texas-Mexican border. Journal of School Health. 1998; 68(7): 282-8.

42. Sahota P, Rudolf MCJ, Dixey R, Hill AJ, Barth JH, Code J. Evaluation of implementation and effect of primary school based intervention to reduce risk factors for obesity. British Medical Journal. 2001; 323(1): 1-5.

43. Mûkoma W, Flisher AJ. Evaluations of health promoting schools: a review of nine studies. Health Promotion International. 2004; 19(3): 357-68.

44. Lytle LA, Achterberg CL. Changing the diet of America's children: what works and why? Journal of Nutrition Education. 1995; 27(1): 250-60.

45. Nutbeam D. Promoting Health and Preventing Disease: An International Perspective on Youth Health Promotion. Journal of Adolescent Health. 1997; 20(1): 396-402.

46. Visser M. School Register of Needs Survey 1996. Department of Education; 1998.

Indian Journal of Pharmacy Practice, Vol 7, Issue 3, Jul-Sep, 2014 
47. Swart D, Reddy P. Establishing networks for health promoting schools in South Africa. Journal of School Health. 1999; 69(1): 47-50.

48. University Of The Western Cape Health Promoting Schools: Creating a decade of Health Promoting Schools Strengthening Whole School Development, 2nd National Conference on Health Promoting Schools, UWC-Bellville; 2006.

49. Tshabalala-msimang M. School-Based Food Gardens Project, Makana District, Eastern Cape; 2005. Available from http://www.doh.gov.za/ (Accessed 20 August 2009).

50. Umthathi Training Project Annual Report; 2009.

51. Zenzen W, Kridli S. Integrative Review of School-based Childhood Obesity Prevention Programs. Journal of Pediatric Health Care. 2009; 23(10): 24258.

52. Waggie F, Gordon N, Brijlal P. The School, a Viable Educational Site for Interdisciplinary Health Promotion. Education for Health 2004; 17(3): 303-12.
53. Govender RD. The barriers and challenges to Health Promotion in Africa South African Family Practice. 2005; 47(10): 39-42.

54. Monteiro CA, D'a benicio MH, Conde WL, Popkin BM. Shifting obesity trends in Brazil. European Journal of Clinical Nutrition. 2000; 54(1): 342-6.

55. Kim S, Moon S, Popkin BM. The nutrition transition in South Korea. American Journal of Clinical Nutrition. 2000; 71(1): 44-53.

56. Lee MJ, Popkin BM, Kim S. The unique aspects of the nutrition transition in South Korea: the retention of healthful elements in their traditional diet. Public Health Nutrition. 2002; 5(1): 197-203.

57. Steyn NP. Overview and Conclusions: A Perspective on Dealing with Chronic Diseases of Lifestyle in South Africa. In Chronic Diseases of Lifestyle in South Africa.1995; 2005; 249-66.

58. Steyn K, Fourie J, Temple N. editors Cape Town: MRC. Available from http:// www.mrc.ac.za/chronic/cdl1995-2005. pdf (Accessed 1 June 2010)

59. JOOSTE HL. Audit report on Health Promotion Practitioners and Services in Mpumalanga. Mpumalanga: Department of Health; 2006 